\title{
ACROSS-THE-BOARD WAGE INCREASES IN EXTENDED COLLECTIVE AGREEMENTS: FAIR OR UNFAIR?
}

\author{
Julien Hofman
}

LPhil BTheol BL LLB LJC

Emeritus Associate Professor University of Cape Town

\section{SUMMARY}

The article looks at across-the-board increases in collective agreements extended to employers who were not party to the negotiations that produced them. It asks whether having to pay such increases can be unfair to these employers. The article explains the safeguards in section 32 of the Labour Relations Act. It concludes that, although these safeguards are not as clear as they might be, they should protect employers from having to pay unfair across-the-board increases. The article ends by looking at how to simplify the safeguards in section 32 .

\section{COLLECTIVE BARGAINING AND CENTRAL BARGAINING}

In collective bargaining, trade unions negotiate with employers or employers' organisations to settle wages and conditions of service. Collective bargaining is part of the right to fair labour practices guaranteed in the Constitution.

Central bargaining is a form of collective bargaining. In central bargaining, wages and conditions of service for a whole industry are negotiated centrally and embodied in what the Labour Relations Act 66 of 1995 calls a collective agreement. The Constitution does not guarantee central bargaining, but central bargaining is part of the Labour Relations Act. It was also part of the Labour Relations Act 28 of 1956 which was the Labour Relations Act's

The author's thanks go to Tony Cotterell for drawing his attention to the issues he discussed in this article.

S 23(5) of the Constitution of the Republic of South Africa, 1996. Collective bargaining is also embodied in international agreements such as the International Labour Organisation's Convention concerning the Application of the Principles of the Right to Organise and to Bargain Collectively (1949) http://www.ilo.org/ilolex/english/convdisp1.htm (accessed 200903-20). 
predecessor. A feature of central bargaining in South Africa is that the Minister of Labour (the Minister) has the power to extend a collective agreement, provided it meets certain conditions, to all employers and employees in an industry. When this happens, a collective agreement applies to employers and employees who did not take part in the central bargaining that led to the collective agreement.

Supporters of central bargaining say that having the same wages and conditions of service throughout an industry promotes industrial peace. Opponents, on the other hand, point out that central bargaining lacks flexibility and prevents employers from offering employees lower wages or less favourable conditions of service. This, they argue, makes it difficult for an employer who is setting up a new business or who is trying to grow an existing small business, in order to compete with established employers. Because of this, opponents conclude, central bargaining slows economic growth and hinders job creation.

In 2002 Bhorat and others wrote a paper for the International Labour Organization on the South African labour market. ${ }^{2}$ Among the matters the authors considered was whether South Africa's labour legislation put any businesses at a disadvantage. They concluded that in South Africa central bargaining did not hinder informal sector businesses because the Labour Relations Act allowed for exemptions from the terms in centrally negotiated agreements that handicap them. ${ }^{3}$

This article looks at one feature of central bargaining in the Labour Relations Act: extending centrally-negotiated, across-the-board wage increases to those who were not party to the negotiations. Such increases need special attention because, unlike other terms in centrally negotiated agreements, they can result in some employers having to pay higher wages than others.

Despite their potential for disadvantaging some employers, across-theboard increases have attracted little attention. ${ }^{4}$ There are a variety of reasons for this. First, not all collective agreements contain across-the-board increases. Second, before the Minister can extend a collective agreement, it has to satisfy certain conditions. Third, as already mentioned, an employer who objects to paying an across-the-board increase can apply for, and often will get, an exemption.

The most likely reason for the lack of interest in across-the-board increases is that if a collective agreement does contain such an increase, the Minister can only extend it to non-parties if most of the employers and employees to whom it will apply have already agreed to it. This means an

2 Bhorat, Lundall and Rospabe The South African Labour Market in a Globalizing World: Economic and Legislative Considerations (2002) http://www.ilo.org/public/english/ employment/strat/download/ep32.pdf (accessed on 2009-03-20).

3 Bhorat et al 49-53.

4 Brand "The National Bargaining Council for the Road Freight Industry - A South African Case Study" (25-05-2006) http://www.bowman.co.za/LawArticles/Law-Article.asp?id= 290673766 (accessed on 2009-03-20), eg, does not mention the across-the-board increases in the collective agreements negotiated in the council. 
extended across-the-board increase will probably affect only employers with fewer employees. These employers, if they do not get exemptions, may not have the resources to challenge either the exemption process or the validity of the extended across-the-board increase. As a result, problems with extended across-the-board increases are less likely to come to the attention of other employers and, in particular, of those responsible for the Labour Relations Act. It is the purpose of this article to draw attention to these problems and to the solutions contained in the Labour Relations Act.

Central bargaining and across-the-board increases are contentious matters. This article does not set out either to support or to oppose the general principles of central bargaining and extending the terms of collective agreements to non-parties.

\section{INCREASES AND ACROSS-THE-BOARD INCREASES}

It may be helpful to begin by explaining the difference between a wage increase and an across-the-board wage increase.

Collective bargaining can involve negotiating either a minimum wage or what is known as an actual wage. A minimum wage is usually expressed as a fixed amount. ${ }^{5}$ Most collective agreements are complex and recognise different categories of employees, with each category having its own minimum wage.

A simple increase in minimum wage benefits those who are earning the minimum wage. It does not, however, benefit an employee who is already earning as much as or more than the new minimum wage. To address this, some collective agreements deal with actual wages. They combine a minimum wage with an across-the-board increase for all employees. An across-the-board increase is usually expressed as a sum of money to be added to the wages of all employees. ${ }^{6}$

An employer is never free, of course, to reduce an employee's wage. ${ }^{7}$ But an employer who does not have to pay an across-the-board increase does not have to increase the wages of employees who are earning more than the minimum wages. Such an employer can allow their wages to stay the same until they are less than the minimum wage. An employer who is already paying more than the minimum wage, on the other hand, and who has to

5 Clause 4(1) of the 2001 collective agreement in the National Bargaining Council for the Road Freight Industry, Johannesburg on 9 January 2001, eg, laid down a new minimum weekly wage of R314 for a general worker (class 1B).

6 Clause 4(6) of the Road Freight Industry collective agreement of January 2001, for example, provided: "[E]mployees who prior to the 1 March 2001 were in receipt of a wage equal to or higher than the minimum prescribed for their class in Government Notice No 400 of the 20 April 2000 shall be awarded wage increases as specified in Table B." Table B, headed "Across-the-board increases (per week)" awarded a general worker an increase of R25. An increase can also be expressed as a percentage of the existing wage.

7 Reducing an employee's wage is an unfair labour practice in terms of $s$ 186(2)(a) of the Labour Relations Act. 
pay an across-the-board increase will have to go on paying more than the minimum wage.

\section{NEGOTIATING WAGE INCREASES}

Across-the-board increases are not a required part of a collective agreement. They are negotiated, with the other terms of a collective agreement, in the bargaining council responsible for an industry. Small businesses can take part in these negotiations. Section 30(1)(b) of the Labour Relations Act even says "the constitution of every bargaining council must provide for the representation of small and medium enterprises". But being represented in collective bargaining is not the same as being able to influence the terms of the agreement that comes out of the bargaining. The big players in a bargaining council, the trade unions with most members and the employers with most employees, will be able to dominate negotiations. Trade unions will argue for across-the-board increases because they will want increases for all their members, not just for those earning the minimum wage. And employers whose employees are earning only the minimum wage will have no reason to use their bargaining power to keep across-theboard increases out of a collective agreement.

This may seem unfair to an employer who is already paying more than the basic minimum wage. Section 31 of the Labour Relations Act, however, says that a collective agreement only binds an employer who, either directly or through membership of an employers' organisation, is party to the agreement. So an employer who does not want to pay an across-the-board increase can choose not to be a party to the collective agreement that contains it.

\section{EXTENDING A COLLECTIVE AGREEMENT TO NON-PARTIES}

It can happen, though, that even an employer who does not want to pay an across-the-board increase and declines to be party to a collective agreement containing it, still has to pay the increase. This is because section 32 of the Labour Relations Act allows the Minister to extend a collective agreement, including any across-the-board increases it contains, to non-parties in an industry or, as section 32 puts it, to non-parties who fall under the "registered scope" of the bargaining council.

In so far as a collective agreement embodies the minimum acceptable conditions of service and wages in an industry, it is hard to argue that it should not apply to everyone in an industry. The Constitution, unlike some other expressions of basic human rights, does not recognise a right to "just and favourable remuneration"8 or to "just and favourable conditions of work". ${ }^{9}$ Receiving such a wage and enjoying such conditions of work,

8 United Nations The Universal Declaration of Human Rights (1948) art 23(3) http://www.un.org/Overview/rights.html (accessed on 2009-03-20).

9 Declaration of Human Rights art 23(1). 
however, are conditions for enjoying many of the rights the Constitution guarantees. So it is difficult to object to such wages and conditions of service being extended to all employees.

Paying a just wage and having favourable conditions of service also benefits employers. It reduces the likelihood of unrest among their employees. And if all employers apply the same standards, no employer will have to compete with other employers who are paying less than the minimum.

It is difficult, however, to use constitutional rights to justify an across-theboard increase that gives some employees more than the minimum wage. The justification for an across-the-board increase is that the negotiating parties agreed to it. They did this, presumably, because the increase was part of a package that, taken as a whole, they regarded as worthwhile. Yet an employer who does not take part in or has withdrawn from negotiations never accepted the package as worthwhile.

Having to pay an across-the-board increase may even penalise an employer. This will be the case if the competitive advantage that originally made it possible for an employer to pay more than the minimum wage, such as access to some new technology or good performance by employees, has disappeared. If the competitive advantage has disappeared, having to pay an across-the-board increase will make it difficult for such employer to compete with other employers who are paying only the minimum wage.

According to the courts, the justification for extending a collective agreement to non-parties is majoritarianism. Majoritarianism, here, means that when a collective agreement applies to most, it should apply to all. "(M)ajoritarianism," as the Court put it in Mzeku v Volkswagen, ${ }^{10}$ commenting on the case of a union member who resigns from a union but is still bound by a collective agreement into which the union entered "is the system that the Legislature has preferred in a number of areas in our labour relations system."

The Legislature may prefer majoritarianism but, when it promulgates the Labour Relations Act, it recognised that majoritarianism, in the form of extending a collective agreement to non-parties, can be unfair. To avoid this, section 32 limits the Minister's power to extend a collective agreement to non-parties. The limitations come under three main heads. First, the Minister must be satisfied the collective agreement has majority support in the sector. Second, the Minister must be satisfied that "the terms of the collective agreement do not discriminate against non-parties". Third, the collective agreement must contain provisions for exempting non-parties from unfair provisions. The article will consider these in more detail.

\section{EXEMPTIONS FOR NON-PARTIES}

The provisions dealing with exemptions come at the end of section 32 . In practice, however, an employer who does not want to pay an across-the-

Mzeku v Volkswagen SA (Pty) Ltd 200122 ILJ 1575 (LAC) 1594 par 55. The court was Zondo JP, Davis and Du Plessis AJJA. 
board increase is likely to start by applying for an exemption. So, we will deal first with exempting non-parties from unfair provisions.

The Labour Relations Act does not itself contain a procedure for applying for an exemption. It merely says the Minister may not extend any collective agreement to non-parties unless the agreement contains provisions for exempting non-parties from unfair provisions. Section 32(3)(e) put it as follows:

"A collective agreement may not be extended in terms of subsection (2) unless the Minister is satisfied that -

(e) provision is made in the collective agreement for an independent body to hear and decide, as soon as possible, any appeal brought against -

(i) the bargaining council's refusal of a non-party's application for exemption from the provisions of the collective agreement;

(ii) the withdrawal of such an exemption by the bargaining council; ..."

Interestingly, the Labour Relations Act nowhere explicitly gives a bargaining council the power to exempt a non-party from a provision of an extended collective agreement. But it is clear from section 32(3)(e) that a bargaining council has an implied power to grant, refuse to grant, or withdraw an exemption. Without such a power, there would be no point in a collective agreement providing for an appeal against such decisions. ${ }^{11}$

The Labour Relations Act, similarly, has no procedure for a bargaining council to follow when considering an application for an exemption or for an independent body to follow when hearing an appeal. These are also left to the collective agreement. Section 32(3)(f) requires the collective agreement to contain "criteria that must be applied by the independent body when it considers an appeal". Again, the Labour Relations Act does not say what these criteria should be. It requires them only to be "fair and promote the primary objects of this Act".

This does not mean that any criteria will satisfy section 32(3)(f). Section $32(3)(\mathrm{g})$, as we have mentioned, has its own fairness requirement that a collective agreement must satisfy before the Minister can extend it. If section $32(3)(f)$ is to achieve anything, the fairness it requires must go further than section $32(3)(\mathrm{g}){ }^{12}$ Section $32(3)(\mathrm{f})$, for example, might allow an exemption if a non-party employer is not able to afford to pay across-the-board increases without requiring, as section 32(3)(f) does, that this will discriminate against the employer.

Before leaving the question of exemptions from an extended collective agreement, it is important to ask whether there can be an exemption for an extended collective agreement that does not satisfy the conditions in section

11 The power is also implicit in s 30(1)(j) which says: "The constitution of every bargaining council must at least provide for the procedure for exemption from collective agreements ..."

12 When interpreting legislation, the courts are reluctant to find that a section in legislation achieves nothing. An example of this is Ex parte Myburgh (1906) 23 SC 668670 where De Villiers CJ was prepared to read "several villages" as meaning "several communal allotments" in order to make the legislation achieve something. See also Van der Westhuizen J in Stoman v Minister of Safety \& Security [2002] JOL 9408 (T), case no 12055/01 20 (accessed on 2009-03-20). 
32. The problem is that if an extended collective agreement does not satisfy these conditions, the extended collective agreement may be invalid. And if it is, neither the bargaining council nor the independent body will have the authority to exempt an employer from its provisions.

Granting an exemption in such a case, however, would be convenient. Without an exemption, an employer would have to challenge the Minister's action in a court or tribunal. This would be expensive and time-consuming for the employer. It would also be embarrassing for the Minister to have a court or tribunal set aside a collective agreement he has extended. It would be possible, we will consider at the end of the article, to settle this issue by amending section 32 .

\section{CONDITIONS FOR EXTENDING A COLLECTIVE AGREEMENT TO NON-PARTIES}

Section 32 of the Labour Relations Act, as we have said, has conditions that must be satisfied before the Minister can extend a collective agreement. We have already seen that it must have an exemption procedure. In this part of the article, we look at two further conditions: the need for majority support from those who are party to the agreement: ${ }^{13}$ and ensuring the extended collective agreement does not discriminate against non-parties. ${ }^{14}$ Before we do this, however, we need to decide on the legal nature of an extended collective agreement and the effect of not complying with the conditions in section 32 .

\section{Delegated legislation or administrative action?}

The legal nature of an extended collective agreement is important because it may affect how a court decides whether an extended collective agreement that does not comply with section 32 is valid. The question is whether an extended collective agreement is a form of delegated legislation or a contract extended to non-parties by administrative act of the Minister. In the past, the courts used to approach administrative action and delegated legislation differently. ${ }^{15}$ Administrative action now falls under the Promotion of Administrative Justice Act. ${ }^{16}$ It is still not entirely clear, however, how the courts will approach delegated legislation. ${ }^{17}$

Under South Africa's previous labour legislation, an industrial agreement that the Minister extended to employers and employees was a form of

\footnotetext{
S 32(1) and (3) of the Labour Relations Act.

$14 \mathrm{~S}$ of the Labour Relations Act.

15 As Schreiner JA explained in Sinovich v Hercules Municipal Councl 1946 AD 783 802: "The power of the court to declare a by-law invalid is wider than its power to go behind the exercise of a discretion by an official." See the discussion in Baxter Administrative Law (1984, corrected 1989) 447-482, 522-534.

16 Promotion of Administrative Justice Act 3 of 2000.

17 The judgments in Minister of Health $v$ New Clicks SA (Pty) Ltd (Treatment Action Campaign and Innovative Medicines SA as Amici Curiae 20061 BCLR 1 (CC) appear to leave this point open.
} 
delegated legislation. ${ }^{18}$ As O'Regan $\mathrm{J}$ said in Fredericks $v$ MEC of Educational Training, Eastern Cape: ${ }^{19}$

"It was well-established in our law that once an agreement was promulgated in this way, its status and binding force derived from the fact that it became a form of delegated legislation."

This meant that an extended industrial agreement had to satisfy all the requirements for delegated legislation including, as O'Regan $\mathrm{J}$ says, promulgation.

Under the Labour Relations Act, however, a collective agreement, as the name suggests, is better seen as a contract agreed in the bargaining council. It is not necessary for the Minister to promulgate it as delegated legislation. $^{20}$ Its effectiveness depends on the consent of the bargaining parties.

When the Minister extends a collective agreement to non-parties, the nonparties have not agreed to the terms of the collective agreement. But this lack of agreement does not necessarily mean that for non-parties an extended collective agreement is a form of delegated legislation. If it were, a collective agreement extended to non-parties would either change its nature from contract to delegated legislation or would be delegated legislation for non-parties, while remaining a contract for those who took part in the collective bargaining. Both these possibilities seem unlikely. They could result in an extended collective agreement having two meanings, either at the same time or consecutively, depending on whether a court was interpreting it as a contract or as delegated legislation. ${ }^{21}$

The better view, therefore, is that for both non-parties and parties, an extended collective agreement is a contract. The difference is that for parties the collective agreement is a contract resulting from their consent. Nonparties, on the other hand, become parties to the contract through administrative action by the Minister. ${ }^{22}$

\section{Mandatory and material conditions}

As a form of administrative action, extending a collective agreement to nonparties will have to comply with the non-parties' constitutional right to fair administrative action in section 6(2)(b) of the Promotion of Administrative Justice Act:

18 An industrial agreement in the Labour Relations Act 28 of 1956 was the predecessor to a collective agreement in the Labour Relations Act.

19 Fredericks v MEC of Educational Training, Eastern Cape 20022 SA 693 (CC) 709.

20 S 31 of the Labour Relations Act is headed "Binding nature of collective agreement concluded in bargaining council" and says: "Subject to the provisions of section 32 and the constitution of the bargaining council, a collective agreement concluded in a bargaining council binds - ..."

21 For a discussion of the differences between interpreting legislation and contracts, see Cornelius Principles of the Interpretation of Contracts in South Africa (2002) 66-70.

22 Christie The Law of Contract in South Africa 5ed (2006) 81. Christie gives s 23(1)(d) of the Labour Relations Act as an example of a contract created by legislation rather than consent. 
"A court or tribunal has the power to judicially review an administrative action if a mandatory and material procedure or condition prescribed by an empowering provision was not complied with;"

The conditions in section 32 of the Labour Relations Act are both mandatory and material. They are material because they protect non-parties to a collective agreement from having to comply with unfair terms. That they are mandatory appears from the peremptory language in section 32. Section 32(3), for example, says a collective agreement "may not be extended" unless the conditions in section 32(3) are met. Section 32(3) also requires the Minister to be "satisfied" the conditions are met. In ordinary conversation being satisfied may have a subjective meaning of being happy or contented. In legal writing, to satisfy usually means to comply with in an objective rather than a subjective sense. ${ }^{23}$ It seems, therefore, that section 32(3) requires that a collective agreement must comply with the conditions before the Minister can validly extend it.

\section{Support from the majority}

Returning to the conditions in section 32 , we have said the Minister can only extend a collective agreement to non-parties if the agreement has majority support. ${ }^{24}$ Section $32(1)$ spells out what this means. First, in the bargaining council that negotiated the collective agreement the trade unions whose members make up a majority of employees and the employers who employ a majority of employees must vote for the extension. Second, should the Minister extend the collective agreement, a majority of employees to whom the extended collective agreement will apply must be members of the trade unions and employees of the employers who negotiated the collective agreement. $^{25}$

Section 32(1) speaks of a bargaining council asking the Minister to extend a collective agreement. But clearly, if a request from a bargaining council satisfies the conditions in section 32 , the Minister must extend the collective agreement. The Minister's discretion extends only to when exactly, during a 60 day period from the time of receiving the request, the collective agreement will begin to apply to non-parties. The Minister can also decide

23 See, eg, WUSA v Crouse NO [2005] 11 BLLR 1156 (LC) where Murphy AJ gave an objective meaning to the word "satisfied" in ss $96(3)(b)$ and $96(4)$ of the Labour Relations Act.

24 S 32(2) of the Labour Relations Act allows the Minister, in specified circumstances, to extend a collective agreement that does not meet the conditions in s 32(3)(b) and (c).

25 The Minister must be satisfied, according to $s 32(3)(b)$, that "the majority of all the employees who, upon extension of the collective agreement, will fall within the scope of the agreement, are members of the trade unions that are parties to the bargaining council;" and, according to $s 32(3)(\mathrm{c})$, that "the members of the employers' organisations that are parties to the bargaining council will, upon the extension of the collective agreement, be found to employ the majority of all the employees who fall within the scope of the collective agreement". 
for how long the collective agreement will apply to non-parties. ${ }^{26}$ The reality, therefore, is that it is the bargaining council, not the Minister, that has the power to extend a collective agreement to non-parties. ${ }^{27}$

If the collective agreement contains across-the-board increases, extending the agreement could result in some employers on the bargaining council strengthening their position in an industry by compelling non-party employers to pay higher wages than they themselves are paying. So, a court considering the validity of an extended collective agreement that contains across-the-board increases, should pay particular attention to the other conditions in the Labour Relations Act. As Tredgold CJ said about a similar piece of legislation: ${ }^{28}$

"[W]hen an agreement affects the interest of non-parties and of the public at large, other and wider considerations arise and it can scarcely have been intended that people whose own vital interests are involved should be left as the final arbiters as between themselves and the public."

\section{No discrimination against non-parties}

The second condition for extending a collective agreement is that the Minister may not do this unless satisfied, as section 32(3)(g) of the Labour Relations Act says, that "the terms of the collective agreement do not discriminate against non-parties".

Du Toit et al say "discriminate" in section 32(3)(g) means "imposing less favourable treatment or unjustifiable disadvantages" but they give no authority for this interpretation and no examples of what it means in practice. ${ }^{29}$ Discrimination, of course, dealt with the equality clause in the Constitution. ${ }^{30}$ Deciding, however, whether an extended collective agreement will discriminate against non-parties is not a matter of applying the constitutional test. ${ }^{31}$ Rather, it depends on what discriminate means in section 32(3) $(\mathrm{g})$ of the Labour Relations Act.

The Labour Relations Act itself does not define "discriminate". In legal discussion, "discriminate" has both a common law and a constitutional meaning. Commenting on the common law, Du Plessis says: ${ }^{32}$

26 S 32(2) and (5) give the Minister the discretion to extend a collective agreement to nonparties where the conditions in section 32 are not satisfied but there is no discretion to refuse to extend a collective agreement where the conditions are satisfied.

$27 \mathrm{~S} 32(7)$ and (10) make it clear that only a bargaining council has the power to cancel an extended collective agreement.

$28 \quad R \quad v$ Campbell (Pvt) Ltd 19562 SA 476 (FC) 478G-H. The case concerned an industrial agreement made in terms of the Industrial Conciliation Act 21 of 1945 of Southern Rhodesia. Tredgold CJ went on to quote what Lord Russell, in Kruse $v$ Johnson [1898] 2 QB 91, said about provisions of this sort: "(T)hey are made by people who "carry on business for their own profit, although incidentally for the advantage of the public' and not by 'public representative bodies clothed with ample authority ... and exercising that authority accompanied by checks and safeguards'."

29 Du Toit, Woolfrey, Murphy, Godfrey, Bosch and Christie Labour Relations Law: A Comprehensive Guide 3ed (2000) 215.

$30 \mathrm{~S} 9$ of the Constitution of the Republic of South Africa, 1996.

31 As, eg, Van Deventer J explained it in Roman v Williams 19981 SA 270 (C).

32 Du Plessis Re-Interpretation of Statutes (2002) 160. 


\begin{abstract}
"These modest judicial rejections of inequality, typical of a fragmented body of case law on equality, have since 1994 been overridden by a powerful and consolidated constitutional jurisprudence on equality and non-discrimination based on two supreme constitutions."
\end{abstract}

If "discriminate" in section 32 has its constitutional meaning it seems, from what the Constitutional Court said in Prinsloo $v$ Van der Linde ${ }^{33}$, that compelling some employers to pay more than their competitors is differentiation rather than what section 8(2) of the Bill of Rights calls unfair discrimination. And "differentiation", unless it harms a person's dignity is not unconstitutional unless "there is no rational relationship between the differentiation in question and the governmental purpose which is proffered to validate it". ${ }^{34}$ In the present case, compelling one employer to pay higher wages than another does not harm the employer's dignity. It is also possible to argue there is a rational relationship between imposing a collective agreement on non-parties and purpose of the Labour Relations Act. The prospect of having to pay an across-the-board increase, for example, is an incentive to employers who do not want to pay the increase to take part in collective bargaining and argue against it. ${ }^{35}$ It is possible, therefore, that compelling a non-party to pay an across-the-board increase would not be discrimination in the constitutional sense of having no rational relationship with the purposes of the Labour Relations Act.

The common law meaning of discriminatory may be, as Du Plessis says, modest and fragmented. It is, however, wider and easier to apply than the constitutional meaning. It can have a wider meaning than discrimination in the Constitution because the common law, unlike the Bill of Rights, cannot prevail over legislation. This means that it is only an aid to interpreting legislation and cannot, as is the case with the Bill of Rights, limit the freedom of legislators to decide policy.

According to the common law, discriminatory provisions are those that are "partial and unequal in their operation as between different classes" ${ }^{36}$ It is not necessary to ask whether there is a rational relationship between extending the collective agreement and the purpose of the empowering legislation. Giving "discriminate" in section 32(3)(g) of the Labour Relations Act its common law meaning does not make all across-the-board increases extended to non-parties discriminatory. Having to pay the increase may well have serious consequences for an employer who is paying more than the minimum wages. The employer may not, for example, be able to afford to pay the increase. Or the employer may be able to pay the increase but has

33 Prinsloo $v$ Van der Linde 1997 3 SA 1012 (CC) 1024-5 par 25.

34 Par 26. S 6(2)(F)(ii) of the Promotion of Administrative Justice Act embodies the same idea.

The long title of the Labour Relations Act gives "to promote and facilitate collective bargaining at the workplace" as one of the purposes of the Labour Relations Act. See the comments of Zondo JP in Kem-Lin Fashions CC v Brunton [2001] 22 ILJ 109 (LAC) 115 par 15 and 20-21. An incentive of this sort, of course, limits the freedom of employers to engage in collective bargaining which, according to Du Toit et al 240-245, is one of the features of the Labour Relations Act.

36 Centlivres CJ in R v Abdurahman 19503 SA (A) 136143 quoting Lord Russel CJ in Kruse $v$ Johnson [1898] 2 QB 91. 
planned to use the money in some other way. These do not make an acrossthe-board increase discriminatory. For an across-the-board increase to be discriminatory the employer who has to pay more than the minimum wage must have at least one competitor who is paying only the minimum wage and who will then have a competitive advantage. This is a factual question. If there is no such competitor, section $32(3)(\mathrm{g})$ is no obstacle to the Minister extending the collective agreement. ${ }^{37}$

In practice, however, even if there is a competitor who benefits from the extended across-the-board increase, the cost may deter non-parties from taking the Minister on review. So, employers will prefer an exemption from an across-the-board increase from the bargaining council if, as explained above, an exemption is possible in these circumstances.

\section{SEVERING AN ACROSS-THE-BOARD INCREASE?}

Before ending this discussion, it is important to ask whether an across-theboard increase that is unfair can be severed or deleted from an extended collective agreement. This might happen in two ways. First, a court might want to sever an unfair term from a collective agreement the Minister has extended in order to save the extended collective agreement. Second, the Minister might want to sever an unfair term from a collective agreement before extending it to non-parties.

It seems, regardless of whether an extended collective agreement is a contract or delegated legislation, that a court does have such a power. It is well established that a court has the power to save defective delegated legislation by severing unlawful provisions ${ }^{38}$ and a similar power to save a contract by severing an illegal term. ${ }^{39}$

In the case of the Minister, the Labour Relations Act does not expressly give the power to delete an unfair term before extending a collective agreement. It is possible, however, that the Minister has an implied power to do this. Steyn JA framed the test for an implied power in Lekhari $v$ Johannesburg City Council: ${ }^{40}$

"It should be emphasised, I think, that in order that such a power may be implied, it is not sufficient that its existence would be reasonably ancillary or incidental to the exercise of any express power, in the sense that it would be

37 Extending a collective agreement without looking into this possibility will be a ground for a court or tribunal to set aside the Minister's action. S 6(2)(b) of the Promotion of Administrative Justice Act reads: "A court or tribunal has the power to judicially review an administrative action if a mandatory and material procedure or condition prescribed by an empowering provision was not complied with ..."

38 As Leach J explained in Mahambehlala v MEC for Welfare, Eastern Cape 20021 SA 342 (SE) 350: "where it is possible to separate the good from the bad in subordinate legislation, and where the good is not dependent upon the bad, then that part of the statute which is good should be given effect to provided that what remains carries out the main object of the statute". See also the comments of Mokgoro J and Sachs J in Bel Porto School Governing Body v Premier, Western Cape 20023 SA 265 (CC) 326-327 par 187; and Cameron v Bray Gibb \& Co (Pvt) Ltd 19663 SA 675 (R) 676-677.

39 As explained in Sasfin (Pty) Ltd $v$ Beukes 19891 SA 1 (A).

$40 \quad$ Lekhari v Johannesburg City Council 19561 SA 552 (A) 567. 
useful in giving effect to that power. It must be reasonably necessary for that purpose. The test is not mere usefulness or convenience, but necessity."

In the present case, extending collective agreements to non-parties is clearly an important feature of the Labour Relations Act. The question is whether the power to delete an unfair term is necessary for the Labour Relations Act to achieve its purpose or merely useful. The power may be necessary because, without such a power, the Minister cannot extend to non-parties a collective agreement containing an across-the-board increase if the across-the-board increase will discriminate against non-parties. This argument, of course, assumes that extending a collective agreement to nonparties is a purpose of the Labour Relations Act.

Severing can only take place subject to conditions. With delegated legislation, severing can only take place if the legislation can still achieve its purpose without the severed provisions. Whether this is the case with an across-the-board increase in a collective agreement will depend on the collective agreement. If the across-the-board increase is the main or only purpose of the collective agreement, severing it from a collective agreement would make it impossible for an extended collective agreement to achieve its purpose. Usually, however, a collective agreement provides not only for a minimum wage but also for conditions of service such as leave, overtime, pensions and insurance. Where this is the case, an extended collective agreement without its across-the-board increases will still achieve its purpose. ${ }^{41}$ The conditions for severing a provision from a contract are similar. ${ }^{42}$

If a court or the Minister severs an across-the-board increase from the extended collective agreement, the across-the-board increase should still bind employers who were party to the agreement. Employers who were party to the agreement differ from non-parties. They agreed to pay acrossthe-board increases and there is no reason to exempt them.

\section{CONCLUSION}

In conclusion, the safeguards in section 32 of the Labour Relations Act should ensure a collective agreement is not extended unfairly to non-parties. If it is extended, they should ensure that a non-party will get an exemption from an unfair across-the-board increase. As this article has tried to show, however, the safeguards in the Labour Relations Act are complex. It is possible that the Minister extending a collective agreement, the bargaining council hearing a request for an exemption or the independent authority hearing an appeal may not be as sympathetic to employers as, according to this article, the legislation requires.

41 Centlivres CJ stated the test for severing provisions from delegated legislation in Johannesburg City Council v Chesterfield House (Pty) Ltd 19523 SA 809 (A) 822. See the discussion in Baxter 679-681.

42 See Van Rensburg, Lotz, Tar and Van Rhijn "Contract" in LAWSA 9(1) 2ed updated Sharrock (2003) par 170. 
The main purpose of this article has been to explain the safeguards in the Labour Relations Act. Understanding these safeguards will allow an employer to whom an across-the-board increase has been extended, to decide whether the Minister, bargaining council or independent body may have acted unfairly and whether it is worth taking them on review.

It would be possible, however, to revise section 32 of the Labour Relations Act to make the section clearer and so reduce the likelihood of needing a review. The simple way would be to exclude all across-the-board increases from any extended collective agreement. If this is not acceptable, the Labour Relations Act could be amended to spell out the grounds for an exemption rather than leaving this to the organisations that negotiate the collective agreement. Such grounds might include some or all of the conditions for extending a collective agreement. 